\title{
Roof characteristics for integrated solar collection in dwellings of Real- Estate developments in Concepción, Chile
}

\author{
Características de techumbre para captación solar integrada en viviendas de conjuntos \\ inmobiliarios de Concepción, Chile
}

Esteban Zalamea (Main and Contact Author)

Universidad del Bío Bío; Depto. Diseño y Teoría de la Universidad del Bío Bío, Concepción, Chile. estebanfzl@gmail.com

Av. Collao 1202, Concepción, Chile, CP 4051381

+56 $423111400 / 56$ (9) 56595727

\author{
Rodrigo Garcia Alvarado \\ Universidad del Bío Bío, Depto. Diseño y Teoría de la \\ Arquitectura, Concepción, Chile. \\ rgarcia@ubiobio.cl \\ 56 (41) 3111409
}

\author{
Manuscript Code: 0363 \\ Date of reception/acceptation: 01Jun2014/01dec2014
}

\begin{abstract}
Resumen
Este artículo presenta un análisis de techumbres de viviendas unifamiliares recientes en Concepción, Chile, con el objetivo de determinar su potencial de captación solar integrada, buscando promover la instalación de sistemas domésticos renovables frente a la creciente demanda energética residencial. Se analiza un registro de 2.139 viviendas de la comuna construidas después del 2006 (que corresponden a un $68,28 \%$ del total en el periodo), las cuales presentan cubiertas inclinadas con una superficie media de $84,7 \mathrm{~m}^{2}$ por unidad, divididas entre tres y doce alas con inclinación media de $37,48^{\circ}$, con un ala mayor o secundaria orientada al sol con un promedio de $33,9 \mathrm{~m}^{2}$. Esta superficie recibe una radiación anual total entre $954 \mathrm{kWh} / \mathrm{m}^{2}$ a $1.732,8 \mathrm{~kW} / \mathrm{m}^{2}$ según azimut $\mathrm{e}$ inclinación, que con paneles fotovoltaicos integrados de un rendimiento regular, pueden otorgar una media de $6.317,2 \mathrm{kWh}$. Esta producción puede suplir cabalmente el promedio de consumo eléctrico anual, con remanentes temporales para la red urbana o contribuir para calefacción. Se estima también una producción dual con tecnología térmica-fotovoltaica, que puede duplicar la generación de energía útil. Los resultados expresan una adecuada relación de recolección solar integrada en techumbres con las condiciones del desarrollo residencial en la zona.
\end{abstract}

Palabras Clave: Vivienda, energia solar, techumbre, chile, integración arquitectónica.

\section{Introduction}

Cities have high energy consumption rates that could be offset by tapping into renewable energy sources, taking advantage of the characteristics of the urban environment. Demand and production of renewably sourced energy could even be shared between different urban sectors (Lund, 2012). One example is the use of integrated solar energy collectors in the pitched roofs of the single-family homes common on the periphery of developing cities such as Concepción, Chile. In order to determine the production capacity of such systems, available roof area and possible contribution to domestic requirements must be quantified according to the technology available (IEA, 2012; Lund, 2012). This study reviews the characteristics of residential roofs in Concepción, taking three necessary conditions into consideration: a) the roof area must be sufficiently large and used solely for coverage purposes (and so be available for solar energy collection); b) the roof area must be safe from theft or damage; c) the roof area must have a suitable orientation for

\begin{abstract}
This paper presents an analysis of the roofs of recently built singlefamily homes in Concepción, Chile in order to identify their potential for integrated solar energy collection. It seeks to promote the installation of domestic renewable energy systems in the face of growing residential energy consumption. The study comprises 2,139 homes in the district, all of which are part of residential developments built since 2006 (68.28\% of total homes built over this period). The houses all have pitched roofs with a mean azimuth of $37.48^{\circ}$. The largest or second largest roof section was identified for each housing model, facing north, east or west with an average area of $33.9 \mathrm{sqm}$. This roof surface receives a total annual solar radiation of between $954 \mathrm{kWh} / \mathrm{sqm}$ and $1,732.8 \mathrm{~kW} / \mathrm{sqm}$ (depending on size, azimuth and pitch), which, equipped with average-performance integrated photovoltaic panels, could supply a mean value of $6.317 .2 \mathrm{kWh} /$ year. This production could fully supply the average household annual electricity consumption, with surplus production either fed into the national grid or contributing to household heating needs. Dual production was also assessed with thermo-photovoltaic hybrid technology that could double useful energy production. Results show that the roof characteristics of new housing are compatible with integrated solar collection.
\end{abstract}

Keywords: Housing, solar energy, roofing, chile, architectural integration.

solar energy collection in mid-latitude areas (Gagbert, 2008; Hachem, 2012; CDT, 2013).

Solar active technology must be considered like a complement to pasive strategies (Hatt et al., 2012). Previous studies have already identified that the specific conditions needed for large-scale solar energy collection are present in several urban zones (IEA, 2009; Hachem, 2012), although there is a lack of analyses of building integrated systems (Wall et al., 2012; IEA, 2012). A methodology has been proposed for estimating the solar collection potential of roofs in newbuild homes (Hachem, 2012) (but not in existing homes) and other studies have analysed buildings according to threedimensional aerial surveys (Izquierdo et al., 2007; Lukac \& Zalic, 2013). However, the physical characteristics (shape, surface area, pitch, orientation and relative proportions) of existing roofs have not been reviewed (Hachem, 2012; Gagbert, 2008; MINENERGIA, 2010).

Concepcion is the central district of the main metropolitan area of the south of Chile, with an estimated population of 
230,729 inhabitants (INE, 2014). The city is located close to the Pacific coast at $36.48 \mathrm{o}$, with a temperate seasonal climate and daily temperature oscillations. Recent real-estate market in the city is dominated by single-family homes on residential complexes with similar house models and a variety of roof pitches (Celis et al., 2012). This study seeks to analyse the characteristics of this housing typology with in order to integrate solar energy systems to help supply residential energy demand. This article is structured showing first the methodology applied. Secondly, an analisys of real-estate house tipology according to its roof geometry; then a possible demand is proposed according to local studies and statistics. Third, a possible annual energy production is established through PV (PhotoVoltaic) and PVTa (PhotoVoltaic plus thermal-air capture) technologies integrated, based to possible demands.

\section{Methodology}

This study is developed through a review of recent residential dwellings according to photographic and building records, followed by analysis of roof conditions and incoming radiation and concluding with an estimation of their relationship to residential energy demand according to statistics. The potentials of a hybrid collection and supply system are also explored.

The housing developments are identified from satellite photographs published on Google Earth 7.1.2.2041 in order to determine the areas of the city with most recent residential developments. In Concepcion, the first available satellite photograph dates back to 2002 , but images only began to be updated annually in 2006, hence this was the year chosen as the starting point for analysis, which continues up until 2013. The satellital pictures for the zone were provided by DataGlobe, Cnes/Spotimage and currently by Landsat, and shows properly building disposition according verification on site. Residential developments occupying over $4,000 \mathrm{sqm}$ of urban land, that involves more than ten similar houses, are easily identifiable. The projects identified within the county were then reviewed and the housing models obtained from local government records.

The next stage involved reconstructing the three-dimensional roof layout of each housing model with Archicad 17.0 software in order to calculate roof area in relation to total floor area. The geometry of roofs were then determined in order to decide most preferable section according size and orientation. Whether the bigger plane to North, East or West (called Largest Roof Section: LRS), or the second one (called Second Largest Roof Section: SLRS), selected in the case that bigger is to South. The housing development plans indicated the number and orientation of the respective houses, as well as roof sizes for each model.

The solar radiation was then estimated for the LRS and SLRS roof sections according to the formula given by local authority regulations and solar energy records for the locality for the different orientations and pitches. A fixed percentage was deducted from all the models for potential shading caused by topography, vegetation and neighbouring buildings since the housing models are all of similar height with overshadowing only likely in the marginal hours with low radiation levels. The most preferable pitch and orientation values were then determined in order to decide whether the main or secondary roof section offered maximum exposure to solar radiation in each house. This process identified the most favourable and least favourable cases as well as most typical situations and overall totals. The total energy produced and averages for each case were calculated based on an average-performance photovoltaic system.

Lastly, the solar energy collected on the LRS and SLRS over the year was compared with average energy demands from statistical records for this housing type in the region. Additionally, a building integrated photovoltaic thermal air hybrid system (BIPVTa) was reviewed that would offer a more direct and effective domestic contribution to heating needs. Monthly supply and demand were compared under both average and best-case/worst-case scenarios for the LRS and SLRS in relation to built floor area. Finally, the potential margin of energy supply was quantified.

\section{Development}

\section{Quantification of single-family homes on real-estate residential developments.}

The satellite photographs of the district of Concepcion's urban area between 2006 and 2013 show different sectors modified with regular patterning (especially to the north and east) and on-site verification confirms these to be residential developments (Fig.1).

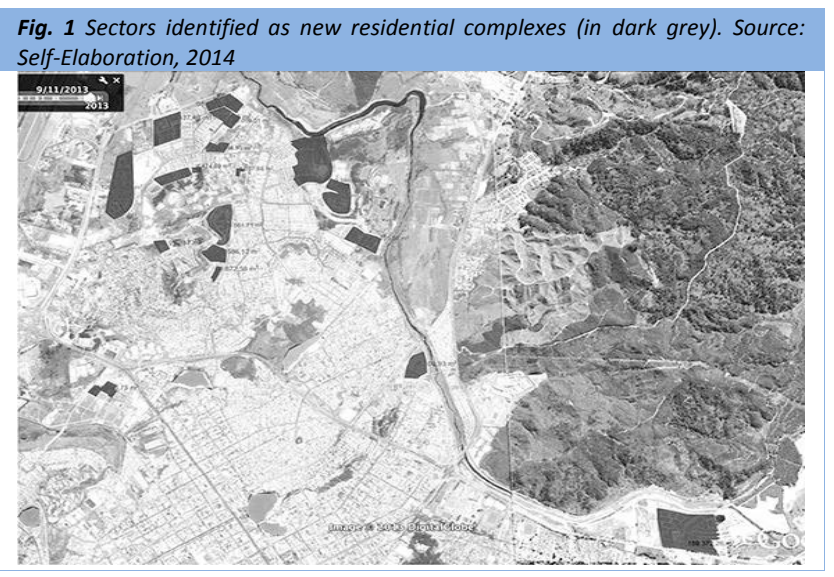

Local authority records for building project approvals identify 22 residential complexes in these sectors with a total of $906,783.4$ sqm of built floor area (corresponding to $90.6 \%$ of the districts approved housing permits for this building type). Construction details were reviewed in the nine complexes with the largest unit numbers, totalling 2,139 homes with $633,350 \mathrm{sqm}$ of built floor area, equivalent to $69.8 \%$ of all the residential complexes and $68.28 \%$ of the total approved residential land area. So, this wide coverage provides a $95 \%$ statistically confidence interval with regard to the housing built over the period, thus providing an accurate representation of current housing development.

\section{Housing characterization by models}

The nine housing complexes reviewed contain 33 different detached, semi-detached or terraced housing models. The number of houses per model varies from 1 to 339 units, although they are quite similar and low amounts of units are models with little variations. The houses have a built floor area of between $57 \mathrm{sqm}$ and $170 \mathrm{sqm}$ each, with an average of $93.32 \mathrm{sqm}$. This average is higher than national 2006 to 
2012 househorld statistic of $68,98 \mathrm{sqm}$, but close to the city average for dwelling units of $88,99 \mathrm{sqm}$ (MINVU, 2013). Almost all the homes $(98.7 \%)$ have two floors and only two models with a total of 28 houses have three floors (none have only one floor). Construction systems are similar: All the first storeys of houses are built on reinforced brickwork while second floors are mostly lighter timber or galvanised metal structures as described by Celis \& others (2012). The roofs consist of pitched planes, with structures either independent or prolongations of the level below, with triangular vertical cross section of timber or metallic roof trusses laid every $50 \mathrm{~cm}$ to $93 \mathrm{~cm}$ horizontally distributed. Horizontal battens or agglomerate timber boards are fixed onto these trusses, with impermeable asphaltic felt laid on top and corrugated metal or fibre cement sheeting to finish (of between $0.4 \mathrm{~mm}$ and $3 \mathrm{~mm}$ thick respectively). Perimeter weatherboards, boiler or heating ventilation tubes, overhanging eaves and gable walls can also be seen (Fig.4)

According to statistics, the energy demand for single-family homes with three to four inhabitants in the city is about $142 \mathrm{kWh} / \mathrm{sqm}$ yearly for space heating, $26.7 \mathrm{kWh} / \mathrm{sqm}$ yearly for electricity consumption and $21.43 \mathrm{kWh} / \mathrm{sqm}$ yearly for hot water supply (CDT, 2010). Therefore, the demand per home in these complexes would be between $1,514 \mathrm{kWh} / \mathrm{sqm}$ yearly and 4,539 $\mathrm{kWh} / \mathrm{sqm}$ yearly for electricity and between $11,008.41 \mathrm{kWh} / \mathrm{sqm}$ yearly and $34,763.4 \mathrm{kWh} / \mathrm{sqm}$ yearly in total, with a mean of $17,794 \mathrm{kWh} / \mathrm{sqm}$ yearly per home.

\section{Roof layout conditions}

The total flat surface area of the roofs in the cases studied is $209,479.9$ sqm ( $23 \%$ of the total development land area), giving an average of $69.9 \mathrm{sqm}$ per house. The pitched roof area of each house is on average $84.7 \mathrm{sqm}$, with a range of between $40 \mathrm{sqm}$ and $130 \mathrm{sqm}$. The different models have between 3 and 12 separate roof sections per house. Most of roofs have 3 to 6 sections of plan surfaces. The larger the house, the more roof sections it tends to possess (Fig.2).

Roof pitches range between $16.7^{\circ}$ and $49.7^{\circ}$, with two modal values of 40.0 o and $26.7 \%$ corresponding to about 1,000 cases ( $47 \%$ of homes analysed). The average pitch of all the models is $37.5^{\circ}$, almost coinciding with the latitude of the city of Concepción: 36.5ㅇ (the most propitious angle for photovoltaic solar collection according to slope). $54.7 \%$ of the houses have a greater pitch than the latitude, making them apt for useful thermal energy collection (Fig. 3). Generally speaking, the roof has the same pitch in each of its sections with only a few exceptions.
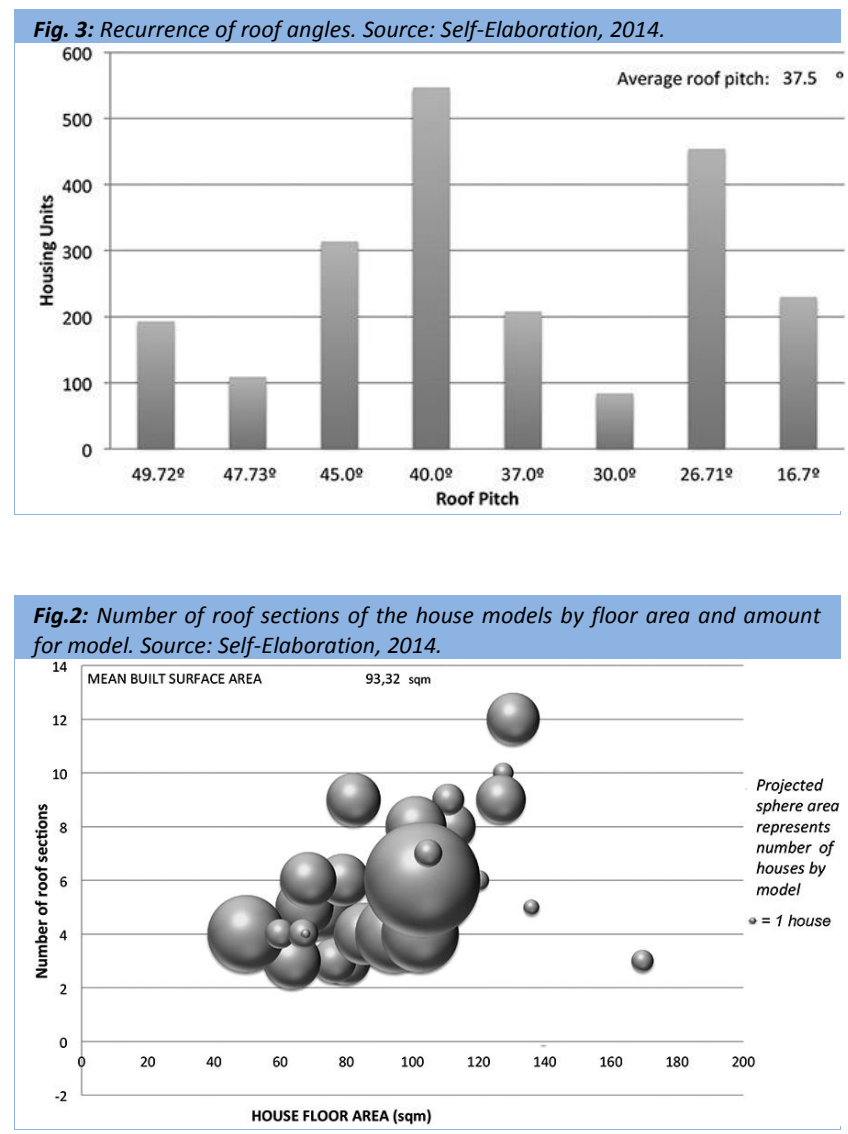

\section{Determining roof sections and azimuths}

Solar energy collection is proportional to the size of the collection area and dependent on pitch and orientation (azimuth) (IEA, 2009; Hachem, 2012), so integrated roof systems must select the most suitable section according to these conditions.

In the models studied, the roof section with the largest roof surface (LRS) was reviewed to identify a relationship with the total built floor area. The result ranged between 0.2 (Model I.1) and 0.62 (Model IX.6) with an average of 0.39 (Fig. 5 \& 6). Calculating the amount of total building plot occupied by the house, the relationship between the LRS and the urban developed land area is 0.13 sqm of collecting surface per 1 sqm of developed land area. In order to determine the orientation of the LRS, the respective roof sections in the four largest residential complexes (1,346 houses, $43 \%$ of total case studies) were classified according to the four directions of the compass, revealing almost equal orientation results in each direction. When the LRS faced the least favourable orientation (south) the second largest roof section (SLRS) was selected in replacement, which in many models was almost the size of the largest roof section or at least well within the size range mentioned at the beginning of the paragraph (over 0.2 ). Figure 6 shows solar potential by model according to their LRS, SLRS and together. 

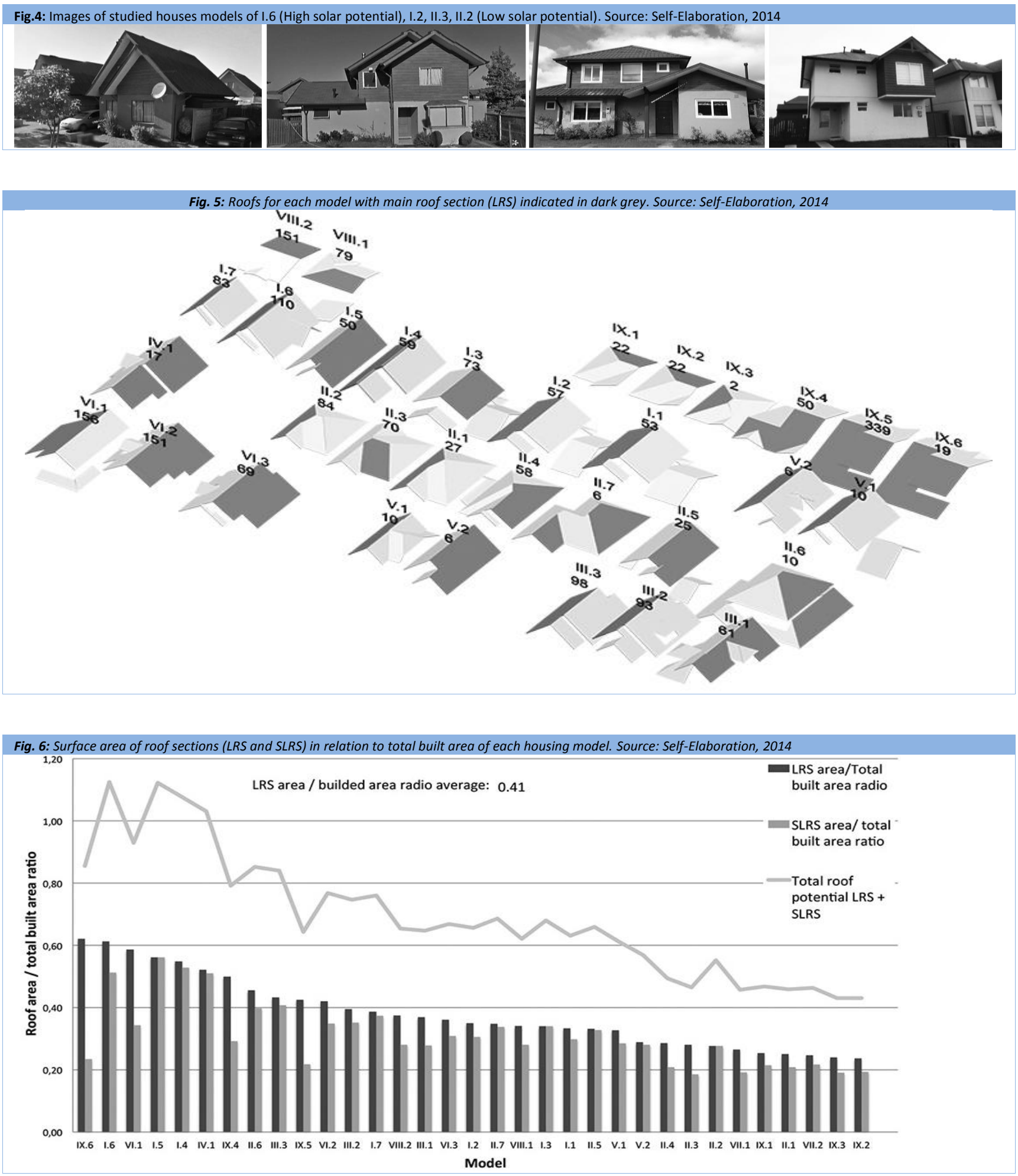

\section{Estimating incoming solar radiation on roofs}

In order to determine overall energy generating potential, the annual radiation was calculated for the LRS and SLRS of each model. The two modal pitch values were used to analyse representative pitches. 1,163 of the house roofs $(54.4 \%)$ were assigned the modal pitch of 43.70 while 976 (45.6\%) were assigned the modal pitch of 26.8 . The monthly horizontal radiation for this latitude per unit of surface area (CDT, 2007), according to the formula given in the current regulations (MINENERGIA, 2010), is as follows in (Eq. 1). Where $R_{\mathrm{Gm} \_ \text {inc-i }}$ : Total mean monthly solar radiation on sloped surface for the month $\mathrm{i}$ in $\mathrm{kWh} / \mathrm{sqm} . R_{\mathrm{Gm} \_\mathrm{i}}$ : Total mean monthly solar radiation on horizontal surface for the month $\mathrm{i}$ in $\mathrm{kWh} / \mathrm{sqm}$. $F_{\mathrm{d}_{\mathrm{i}}}$ : Modifying factor of incoming radiation on sloped surface for the month i. This value is found in the Anexo II of Regulation 20365 (MINENERGIA, 2010). $O_{\text {PS }}$ : Orientation of roof surface in relation to incoming solar radiation. PS : Losses through shading [\%]. These are not factored in initially; a single percentage value is then established for all cases according to previous studies (IEA, 2007).

$R_{\mathrm{Gm} \_ \text {inc-i }}=R_{\mathrm{Gm}_{-} \mathrm{i}} \times F_{\mathrm{d}_{-} \mathrm{i}} \times\left[1-(3,5 / 100000) \times O_{\mathrm{PS}}\right] \times[1-($ $P S / 100)$ ] [Eq. 1] 
In this way the radiation levels are calculated for the two representative roof pitches in the equinox and solstice months in order to reveal how far from due north the LRS must deviate for the SLRS to begin to offer greater collection potential (Table 1). In this regard, it can be seen that when the LRS deviates $113^{\circ}$ from due north, the radiation collected is similar to the SLRS deviated 90ㅇ from due north (for average roof conditions); this figure is thus taken as the statistical deviation for replacing the LRS with the SLRS. The universe of houses is arranged distributively with the LRS collecting radiation within a range of 2260 around due north (between 113을 east of due north and 1130 west of due north), situation corresponding to a total of 1,966 homes. The remaining 1,166 homes collected more energy on their SLRS oriented within a range of $134^{\circ}$ around due north (between 68 east of due north and 68ㅇ west of due north) (Fig. 7).

\begin{tabular}{|c|c|c|c|c|c|c|c|}
\hline \multicolumn{7}{|c|}{$\begin{array}{l}\text { Average radiation per } \mathrm{m} 2 \text { according azimuth and pitch of roof section } \\
(\mathrm{kWh} / \mathrm{m} 2) \text { by equinox and solstice months }\end{array}$} & \multirow{2}{*}{$\begin{array}{l}\text { Radiation diminished } \\
\text { according to SLRSs } \\
\text { index (77.24\%) }\end{array}$} \\
\hline Azimunth(?) & $\operatorname{Pitch}(\%)$ & Jan & Mar & Jun & Sep & Average & \\
\hline \multirow{4}{*}{22.5} & 27.5 & 205.9 & 167.5 & 69.6 & 132.2 & 143.8 & 111.1 \\
\hline & 43.7 & 186.6 & 171.8 & 81.8 & 137.6 & 144.4 & 111.6 \\
\hline & 27.5 & 202.3 & 164.5 & 68.4 & 129.8 & 141.2 & 109.1 \\
\hline & 43.7 & 183.3 & 144.9 & 80.3 & 135.2 & 135.9 & 105.0 \\
\hline \multirow{2}{*}{45.0} & 27.5 & 191.3 & 155.6 & 64.7 & 122.8 & 133.6 & 103.2 \\
\hline & 43.7 & 173.4 & 168.7 & 76.0 & 127.9 & 136.5 & 105.4 \\
\hline \multirow{2}{*}{60.0} & 27.5 & 180.0 & 146.5 & 60.8 & 115.5 & 125.7 & 97.1 \\
\hline & 43.7 & 163.1 & 150.1 & 71.5 & 120.3 & 126.2 & 97.5 \\
\hline \multirow{2}{*}{90.0} & 27.5 & 147.5 & 120.0 & 49.9 & 94.7 & 103.0 & \\
\hline & 43.7 & 133.7 & 123.1 & 58.6 & 98.6 & 103.5 & \\
\hline \multirow{2}{*}{113.0} & 27.5 & 113.9 & 92.6 & 38.5 & 73.1 & & \\
\hline & 43.7 & 103.2 & 95.0 & 45.2 & 76.1 & & \\
\hline \multirow{2}{*}{135.0} & 27.5 & 74.6 & 60.6 & 25.2 & 47.9 & 52.1 & \\
\hline & 43.7 & 67.6 & 59.1 & 29.6 & 117.9 & 68.6 & \\
\hline
\end{tabular}

The angles of roof orientation are classified into ten different ranges. The LRS collects more solar radiation in six of these ranges and the SLRS collects more radiation in the remaining four, with a similar number of houses in each orientation range for both the LRS and SLRS (328 and 292, respectively). The six orientation ranges for the LRS cases are distributed at 37.6 o deviations around due north (firstly up to 18.83 , secondly up to $56.5^{\circ}$ and thirdly up to $94.17^{\circ}$ either side of due north). SLRS orientations fall into ranges of 33.5 deviations around due north (firstly up to $16.75^{\circ}$ and secondly up to $50.25^{\circ}$ either side of due north). East and west facing roofs are assumed to receive similar solar radiation. A total of 656 homes lie within the LRS orientation ranges and 583 homes are within the SLRS ranges. Using formula [1], the monthly radiation received on the LRS and SLRS roofs is estimated for the total number of houses in each orientation range (Table 2).

The houses with LRS with deviations of less than $18.83^{\circ}$ from due north and 43.70 roof pitch receive the most radiation, totalling 21,955.7 MWh/year. The houses with SLRS with a high deviation of 50.25 - from due north and 26.8ㅇ roof pitch collect an annual total of $11,479.9 \mathrm{MWh}$. January is the month with the maximum total radiation of $19,236.0 \mathrm{MWh}$; June has the lowest collection rates for houses with LRS with 94.170 deviation angles but their total energy collection is $12.4 \%$ higher than that of the group of SLRS with 16.24 을 deviation angle.

The calculations for total residential roof area allow a forecast to be made of how much energy could be obtained for domestic use. Factoring in an efficiency level of $16 \%$ for photovoltaic systems and a $25 \%$ energy loss from inverters, distribution, shading, connections, etc., a useful production of $12 \%$ is to be expected (IEA, 2004; Hachem, Athienitis \& Fazio,
2011; Pelland \& Poissant, 2006). The total electricity production for the 3,133 roofs is calculated at $19,788.7 \mathrm{MWh}$ annually, giving an average of 6,317.2KWh per home. A home with the average built floor area of 93.71sqm could expect an annual electricity production of $67.41 \mathrm{KWh}$ per habitable sqm.

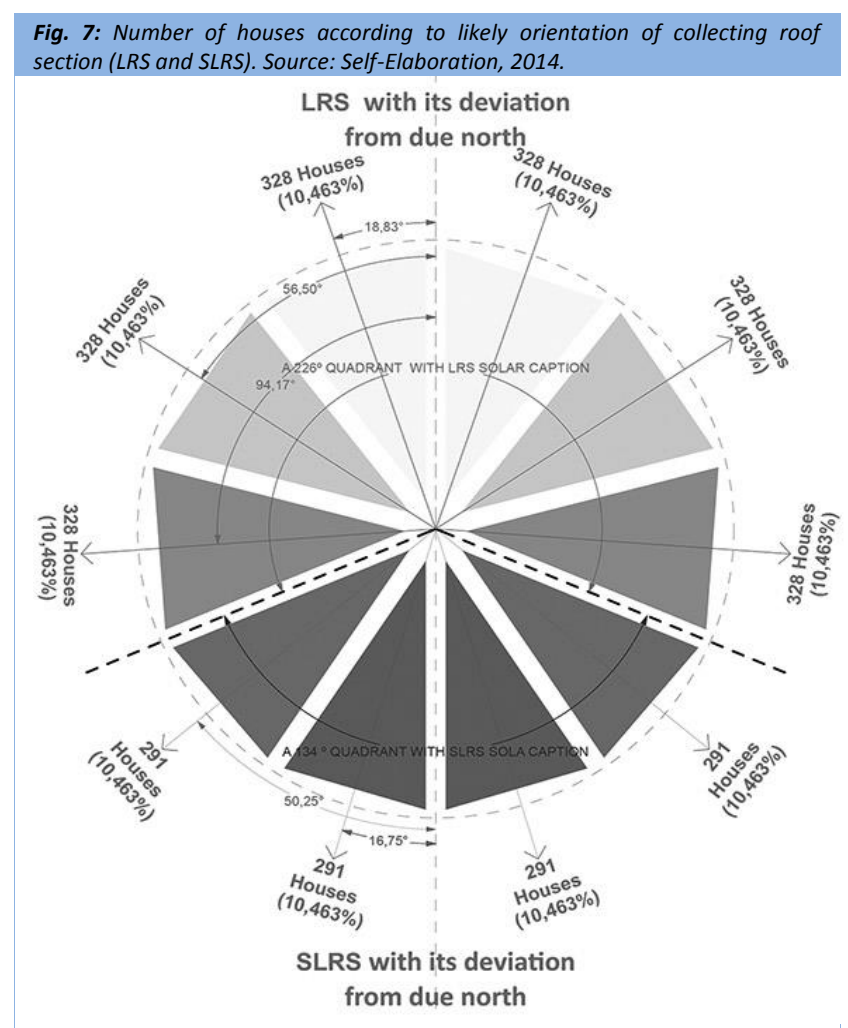

\section{Solar energy supply in comparison with domestic demand}

As mentioned previously, the residential energy demand in the zone largely involves heating needs (concentrated over the winter period) and electricity consumption and hot water supply (the latter two more evenly spread over the year). For this reason, a dual system is recommended where photovoltaic roof panels provide energy to cover household electricity consumption while thermal solar collection is more efficient for providing hot water and space heating needs (Chow, 2009; Athienitis et al., 2010). The annual photovoltaic electricity production in the main or secondary roof section compared with household demand per built square metre demonstrates a significant contribution to electricity needs (Fig.8). These estimates have been calculated using monthly solar radiation records including a margin of variation for more or less favourable circumstances. Although, in the least favourable cases, supply must be supplemented over a brief winter period, production levels are generally higher than household electricity demand and the surplus could either be fed into the national grid (Lund, 2012) or used for other domestic requirements.

In this context, photovoltaic thermal hybrid solar air collectors could be used, like those being tested in Canada since the 1970s (Fig. 9) (Solarwall, 2014). The design of these collectors has arisen from the fact that $85 \%$ of radiation received by the photovoltaic panels is dissipated in the form of heat, generating losses in efficiency of $0.4 \%$ per oc temperature increase (Niccolo, Del Pero \& Leonforte, 2012; 
Hachem C, 2012; Orazio et al., 2013). Hybrid air-based technology places the photovoltaic panels over an airflow chamber to cool the photovoltaic cells and thus maximise their efficiency. Athienitis \& Hachem (2012) suggest a production model with hybrid air collectors placed at an angle of between 30\% and 60\%, mainly 45․ If $Q e$ is the electricity generated and $Q u$ is the total thermal energy generated then the relationship $Q u / Q e=3.0$ to 3.5 if airflow velocity is adequate. Finally, the relationship $3 Q u=Q e$ is proposed for a simple calculation (Hachem, 2012), where thermal energy generated is transferred as warm air and used to heat the house interior. In summer periods the air is evacuated out of the house with a cooling effect.
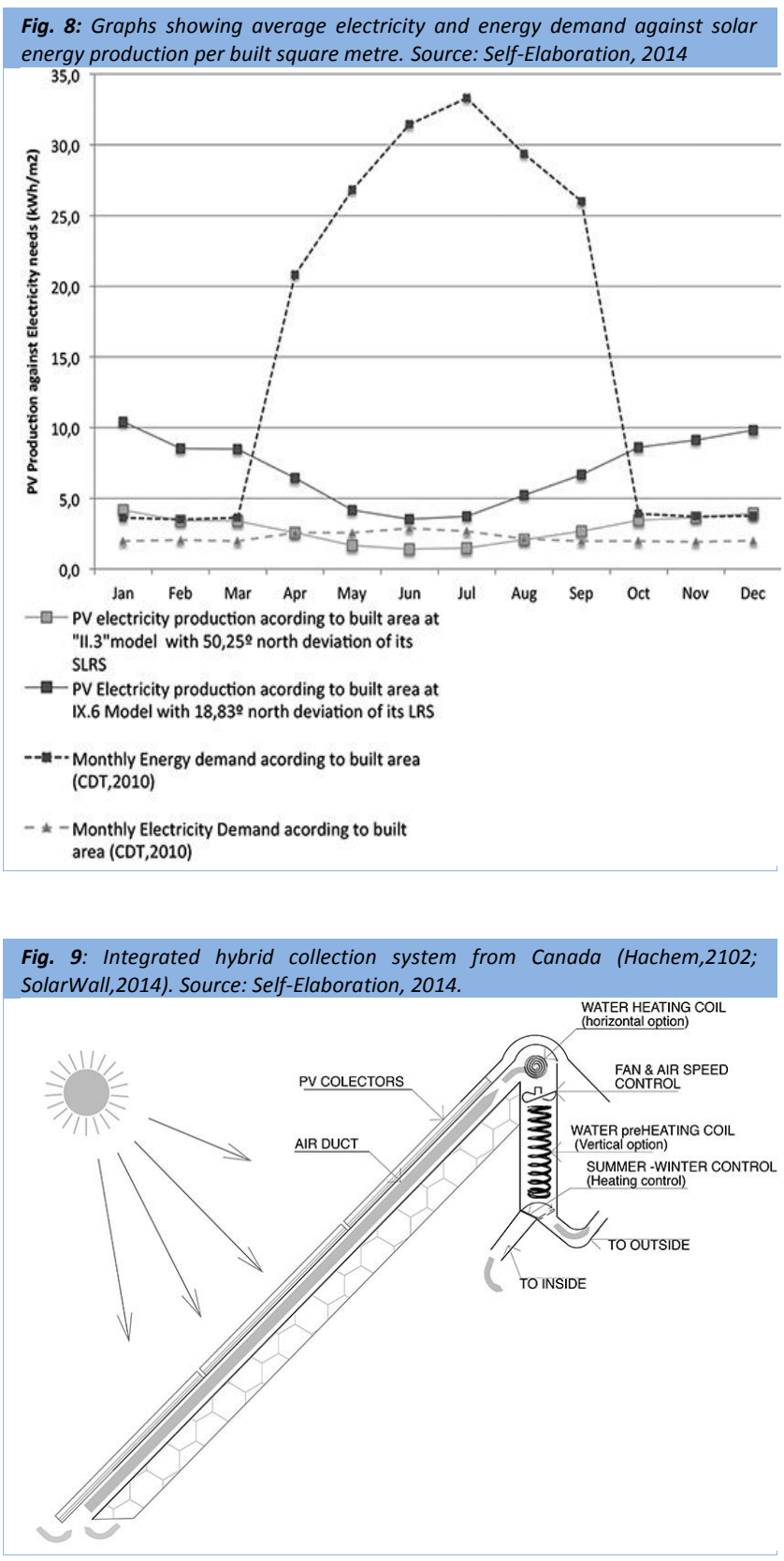

Building-integrated hybrid air systems (BIPVT/a) enable more rapid cost recuperation compared to photovoltaic technology and need smaller collection areas (Athienitis et al., 2010; Siwei \& Paniagota, 2012; Solarwall, 2014). Installation requires the roof surface to be replaced by impermeable metal plates laid over insulation material, an airflow chamber and finally a microperforated corrugated metal plate to collect heat and air and provide rigidity and reduce the need for a supporting structure. Replacing the usual roof covering in this way enables a greater degree of architectural integration than when collectors are laid on top of the roof where installation could compromise roof impermeability. The aforementioned research points to the system's marketcompetitive potential if it were to be developed industrially, promising low costs and energy efficiency.

Using a BIPVT/a system on a main or secondary roof section with this housing type and climate can provide a substantial contribution to domestic heating in the months close to the spring and autumn equinox, as well as over the winter period (Fig. 10). The final balance gives an average annual useful energy production of $142.6 \mathrm{kWh} / \mathrm{sqm}$ (including surplus electricity). This stands against an average total energy demand of $189.9 \mathrm{kWh} / \mathrm{sqm}$. According to these figures, $75 \%$ of average household energy needs could be self-generated in an average $93.7 \mathrm{sqm}$ home with a collecting surface area of $36.8 \mathrm{sqm}$ and $28.4 \mathrm{sqm}$ for the LRS and SLRS respectively.

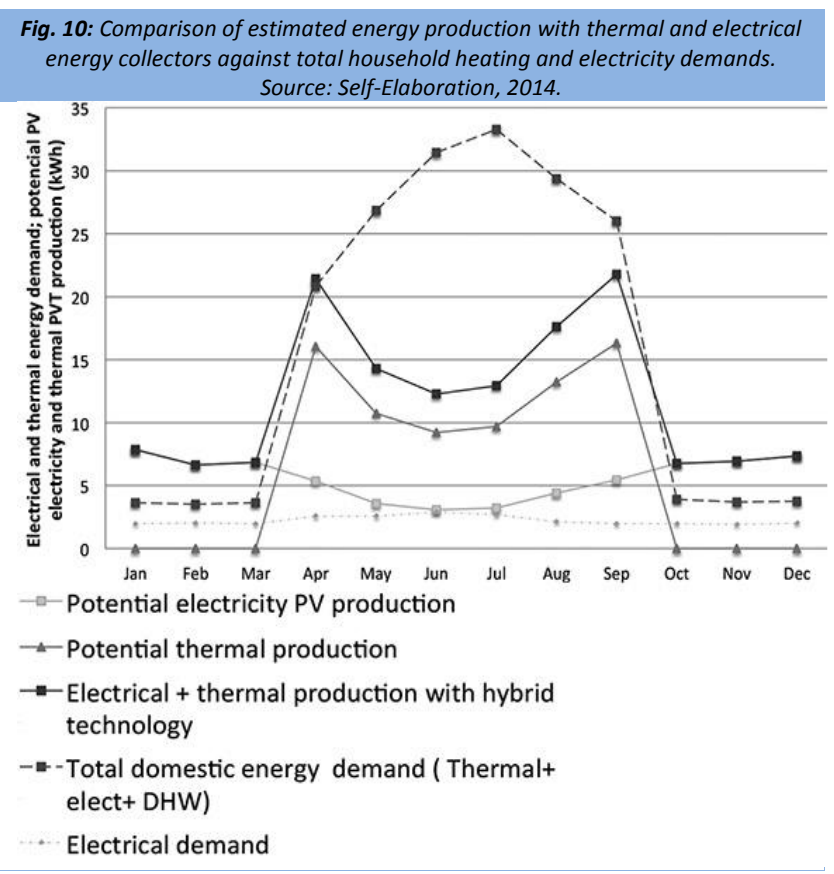

In the most favourable cases, with a higher proportion of roof collecting area in relation to building floor area and good orientation (IX.6, LRS deviated 18.83ㅇ), solar energy can supply $92 \%$ of total domestic demand, although production exceeds demands in April so the effective margin would be between $85 \%$ to $90 \%$ (Fig.11a). In least favourable conditions, with a smaller SLRS area and low or high deviation (II.3 with $50.25 \%)$, solar energy could supply $43 \%$ of total domestic demand (Fig.11b). To cover electricity needs alone, model IX.6 generates $317.1 \%$ of annual demand and model II.3 produces $148.7 \%$. Moreover, improving efficiency by aircooling the photovoltaic cells could also supply warm air either for space heating or ventilation needs (Athienitis et al., 2010). 
Fig. 11a \& 11b: Estimated energy production for housing models with most and least favourable conditions, against demand acordung to built area and CDT, 2010. Source: Self-Elaboration, 2014.

Demand/Production on" IX.6" model.
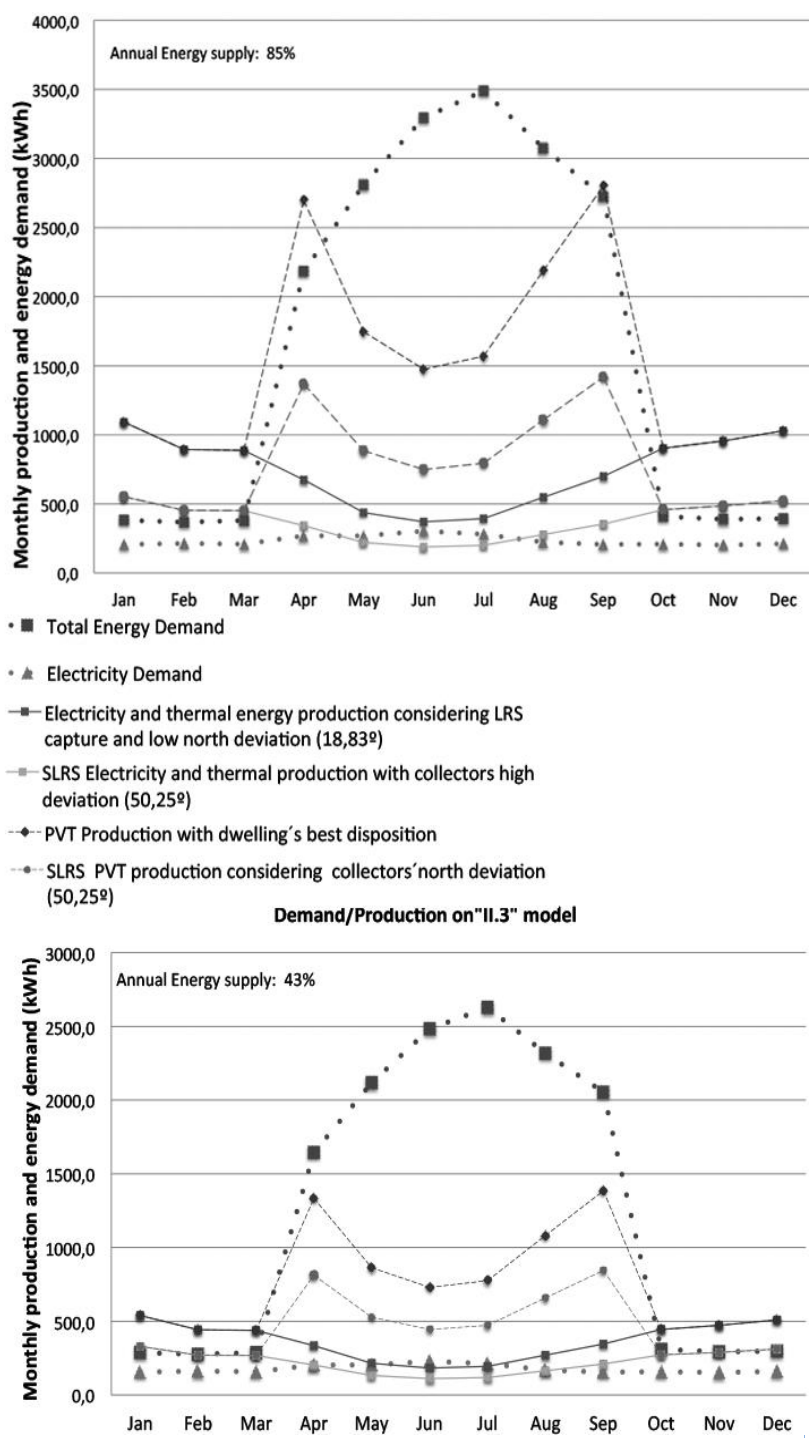

A method has been put forward to quantify photovoltaic and thermal energy production by examining roofs of housing types in residential developments. Analysis was made of the solar potential of recently built single-family houses in Concepción if their main (LRS) or secondary (SLRS) roof sections (as appropriate) were covered in integrated photovoltaic systems. It has been calculated that these roof surfaces could generate a total of $19,788.7 \mathrm{MW} /$ year for 2,139 homes over an area of $633,350 \mathrm{~m} 2$, giving a production rate of $31.24 \mathrm{~kW} / \mathrm{m} 2$ of urban space. This would be enough to supply the full average electricity needs of each home with possible surpluses for the urban grid. An analysis of hybrid collectors (photovoltaic thermal air collectors) is also put forward, following references to a system developed in Montreal, Canada (latitude 45N), although that enjoys different climate conditions to Concepción (37오), but has achieved a substantial contribution (75.1\%) to total domestic energy demand for both space heating and electricity supply. The supply-demand relationship for the models with most and least favourable conditions was also reviewed: those houses with larger LRS and good solar orientation (18.8ㅇ off due north), compared with those with smaller SLRS and bad orientation (50.3ㅇ off due north). With hybrid technology, these cases managed to supply $317.1 \%$ and $148.7 \%$ respectively of their domestic electricity needs and a little less than $91 \%$ and $43 \%$ respectively of their total domestic energy needs.

The results obtained are estimates based on general statistics for energy demand, usual climatic conditions and possible technologies. Cost of installation and maintenance of the systems should be also regarded, as well as the management of supplies to the grid. Although these conditions depends of politic and technological developments, this study suggest that adequate solar collection levels using integrated systems can be achieved on the roofs of a variety of recent housing models. This advocates significant potential for this dwelling type to use this renewable energy source to supply its basic domestic energy needs, as well as contribute seasonal (heating) requirements or return surplus to the urban grid for use in other areas. A more detailed analysis of energy production and demand is now needed for specific building configurations using proven technology or verified simulations. The estimative study carried out has revealed significant possibilities for recently built housing models in the zone to incorporate integrated solar energy collection.

\section{Acknowledgment}

This work is part of Conicyt CONFIN AKA-ERNC 007 research program, (Chile, Conicyt 912, 2013). We are thankful to Dirección de Obras de la municipalidad de Concepción throw Paulina Liberona by municipal data and Secretaria de Educación Superior, Ciencia, Tecnología e Innovación del Ecuador, SENESCYT for financial support. 


\section{References}

Athienitis, A., Bambara James, O’Neill, B., \& Faille, J. (2011). A prototype photovoltaic/thermal system integrated with transpired collector. Solar Energy, 85(1) 139-153.

CDT . (2013). Corporación de Desarrollo Tecnológico. Diseño y Dimensionamiento de Sistemas Solares Fotovoltaicos. Camara Chilena de la Construcción, Corporación de Desarrollo Tecnológico: Santiago, Chile.

CDT. (2010). Corporación de Desarrollo Tecnológico. Estudios de usos finales y curva de oferta de la Conservación de la Energía en el Sector Residencial. Corporación de Desarrollo Tecnológico: Santiago, Chile.

Celis, F., García, R., Maureen, T., Escorcia, O., Bruscatto, M., \& Diaz, M. (2012). Análisis energético de las viviendas del centrosur de Chile. Arquitecturarevista, Vol. 8, n. 1, p. 62-75.

Chow, T. T. (2010, February). A review of photovoltaic/thermal hybrid solar technology. Applied Energy, 87(2), 365-379.

Gajbert, H. (2008). Solar Thermal Energy Systems for Building Integration, PHd Thesis, Lund University [Thesis in English].

Hachem, C., Athienitis, A., \& Fazio, P. (2011, April 27). Parametric investigation of geometric form effects on solar potential of housing units. Solar Energy, 85(9), 1864-1877.

Hachem, C. (2012). Investigation of Design Parameters for Increased Solar Potencial of Dwellings and Neighborhoods, PHd Thesis, Concordia University [Thesis in English].

Hatt, T., Saelzer, G., Hempel, R., \& Gerber, A. (2012). Alto confort interior con mínimo consumo energético a partir de la implementación del estándar Passivhaus en Chile. Revista de la Construcción, 12 (22), 123-134.

IEA (2009). Cities, Towns and Renewable energy. Paris, Francia: Organization for Economic Co-operation and Development. Retrieved from http://www.iea.org/publications/freepublications/publication/cities2009.pdf. [visited 01.01.2014]

IEA (2004). Report IEA PVPS T2-05. TNC Consulting AG. Erlenbach: Swiss Federal Office of Energy. Retrieved from http://www.google.com/url?sa=t\&rct=j\&q=\&esrc=s\&source=web\&cd=1\&ved =0CB8QFjAA\&url=http\%3A\%2F\%2Fwww.ieapvps.org\%2Findex.php\%3Fid\%3D9\%26elD\%3Ddam_frontend_push\%26doclD \%3D197\&ei=2-2UVPKZBFWLSQTO-YKYAw\&USg=AFOjCNGaNGSNh9t58LaLctF710vr9ShHw\&bvm=bv.82001339,d.cWc. [visited 01.01.2014]

IEA (2012). Task 41: Solar Energy Systems in Architecture. IEA Task 41, Solar Heating and Cooling Program. Suecia: Lund University. Retrieved from: http://task41.ieashc.org/data/sites/1/publications/T41DA2-Solar-Energy-Systems-inArchitecture-28March20131.pdf [visited 01.01.2014].

INE (2014). Productos Específicos Demográficos y Vitales. Retrieved from

http://www.ine.cl/canales/chile_estadistico/familias/demograficas_vitales.ph $\mathrm{p}$ [visited 01.01.2014].

Izquierdo, S., Rodriguez, M., \& Fueyo, N. (2007). A method for estimating the geographical distribution of the available roof surface area for large-scale photovoltaic energypotential evaluations. Solar Energy, 82(10), 929-939.

Lukac, N., \& Zalic, B. (2013). GPU-Based roof's solar potential estimation using LiDAR data. Computers a Geoscience 52 , 34-51.
Lund, P. (2012). Large scale urban renewable electricity schemes. Energy Conversion and Management. Energy Conversion and Management 63, 162-172.

MINENERGÍA. Norma Técnica que determina algoritmo para la verificación de la contribución solar mínima de los Sistemas Solares Térmicos acogidos a la franquicia tributaria de la Ley № 20.365. Ministerio de Energía de Chile. Retrieved from http://antiguo.minenergia.cl/minwww/export/sites/default/02_Noticias/desc argas_noticias/Norma_Tecnica_Actualizada.pdf [visited 01.01.2014].

MINVU. Observatorio Habitacional. Ministerio de Vivienda y Urbanismo de Chile, Santiago. Retrived from http://www.observatoriohabitacional.cl/opensite_20080122171157.aspx [visited 01.01.2014]

Niccolo, A., Del Pero, C., \& Leonforte, F. (2012). Optimization of solar thermal fraction in PVT systems. Energia Procedia, 30, 818.

Orazio, M., Di Pierna, C., \& Di Giussepe, E. (2013). Performance assessment of different roof integrated photovoltaic modules under Mediterranean Climate. Energy Procedia, 42, 183-192

Pelland, S., \& Poissant, Y. (2006). An Evaluation of the Potential of Building Integrated Photovoltaics in Canada. 31st Annual Conference of the Solar Energy Society of Canada (SESCI), Quebec.

Siwei, L., \& Paniagota, P. (2012). Evaluation of turbulence models for airflow and heat transfer production in BIPV/T system optimization. Energy Procedia, 30, 1025-1034.

Solarwall. PV/Thermal; Hybrid solar heating + electricity. Retrieved at 2014, from SolarWall by Conserval Energy. Retrieved from http://solarwall.com/en/products/pvthermal.php [visited 01.01.2014].

Wall, M., Maria, M., Roecker, C., Dubois, M.-C., Mijana, H., Olaf, B., y otros. (2012). Achieving Solar Energy in Architecture-IEA SHC Task 41. Energy Procedia, 30, 1250-1260. 
Table 2: Radiation by number of houses according to orientation of LRS and SLRS. Source: Self-Elaboration, 2014.

ANNUAL SOLAR RADIATION RECIBED (MGWh) THROUGH LRS OR SLRS OF REAL-ESTATES' DWELLINGS'ROOFS ACCORDING TO THEIR POTENTIAL

\begin{tabular}{|c|c|c|c|c|c|c|c|c|c|c|c|c|c|c|c|c|c|}
\hline Azimunth(ㅇ) & Pitch () & $\begin{array}{c}\# \text { of } \\
\text { houses }\end{array}$ & $\begin{array}{c}\text { LRS (m2) } \\
\text { or SLRS } \\
(\mathrm{m} 2)\end{array}$ & Jan & Feb & Mar & Apr & May & Jun & Jul & Aug & Sep & Oct & Nov & Dec & $\begin{array}{l}\text { Annual } \\
\text { Average }\end{array}$ & TOTAL \\
\hline & $\begin{array}{c}26.8 \text { ( } 45.6 \% \text { of } \\
655 \text { cases) } \\
43.7(54.4 \% \text { of }\end{array}$ & 299,10 & 37,24 & 2264,8 & 1853,1 & 1842,0 & 1400,1 & 906,2 & 765,6 & 813,9 & 1135,3 & 1453,9 & 1871,2 & 1984,4 & 2136,4 & 1535,6 & 18427,0 \\
\hline 18.83 & $\begin{array}{c}656 \text { cases }) \\
26.8(45.6 \% \text { of }\end{array}$ & 356,41 & 37,24 & 2445,8 & 2123,2 & 2251,4 & 1805,3 & 1234,1 & 1071,9 & 1120,1 & 1503,2 & 1804,1 & 2167,3 & 2169,6 & 2259,9 & 1829,6 & 21955,7 \\
\hline 56.5 & $\begin{array}{c}655 \text { cases) } \\
43.7 \text { (54.4\% of }\end{array}$ & 299,10 & 37,24 & 2036,2 & 1666,0 & 1656,0 & 1258,7 & 814,7 & 688,3 & 731,8 & 1020,7 & 1307,1 & 1682,3 & 1784,1 & 1920,7 & 1380,5 & 16566,5 \\
\hline & $\begin{array}{c}656 \text { cases }) \\
26.8 \text { ( } 45.6 \% \text { of }\end{array}$ & 356,41 & 37,24 & 2198,8 & 1908,8 & 2024,1 & 1623,0 & 1109,5 & 963,7 & 1007,0 & 1351,4 & 1621,9 & 1948,4 & 1950,6 & 2031,7 & 1644,9 & 19738,9 \\
\hline 94.17 & $\begin{array}{c}655 \text { cases) } \\
43.7 \text { ( } 54.4 \% \text { of }\end{array}$ & 299,10 & 37,24 & 2004,3 & 1640,0 & 1630,1 & 1239,1 & 802,0 & 677,5 & 720,3 & 1004,8 & 1286,7 & 1656,0 & 1756,2 & 1890,7 & 1359,0 & 16307,6 \\
\hline & $\begin{array}{c}656 \text { cases }) \\
26.8(48.72 \% \text { of }\end{array}$ & 356,41 & 37,24 & 2164,4 & 1879,0 & 1992,4 & 1597,7 & 1092,1 & 948,6 & 991,2 & 1330,3 & 1596,6 & 1918,0 & 1920,1 & 1999,9 & 1619,2 & 19430,4 \\
\hline $\begin{array}{c}16.75 \text { (SLRS } \\
\text { caption) }\end{array}$ & $\begin{array}{c}583 \text { cases) } \\
43.7(51.28 \% \text { of }\end{array}$ & 266,01 & 28,26 & 1532,4 & 1253,8 & 1246,3 & 947,3 & 613,1 & 518,0 & 550,7 & 768,2 & 983,8 & 1266,1 & 1342,7 & 1445,6 & 2103,4 & 12468,1 \\
\hline & $\begin{array}{c}583 \text { cases }) \\
26.8(48.72 \% \text { of }\end{array}$ & 316,98 & 28,26 & 1654,8 & 1436,6 & 1523,3 & 1221,5 & 835,0 & 725,3 & 757,9 & 1017,1 & 1220,7 & 1466,4 & 1468,0 & 1529,1 & 1238,0 & 14855,7 \\
\hline 50.25 (SLRS & 583 cases) & 266,01 & 28,26 & 1410,9 & 1154,4 & 1147,4 & 872,2 & 564,5 & 476,9 & 507,0 & 707,2 & 905,7 & 1165,7 & 1236,2 & 1330,9 & 956,6 & 11479,0 \\
\hline Caption) & $\begin{array}{c}43.7 \text { ( } 51.28 \% \text { of } \\
583 \text { cases) }\end{array}$ & 316,98 & 28,26 & 1523,6 & 1322,6 & 1402,5 & 1124,6 & 768,8 & 667,7 & 697,7 & 936,4 & 1123,8 & 1350,1 & 1351,6 & 1407,8 & 1139,8 & 13677,1 \\
\hline \multicolumn{2}{|c|}{ TOTAL } & 3132,53 & & 19236,0 & 16237,6 & 16715,5 & 13089,5 & 8739,9 & 7503,4 & 7897,6 & 10774,6 & 13304,4 & 16491,5 & 16963,5 & 17952,6 & 14806,6 & 164906,2 \\
\hline \multicolumn{3}{|c|}{ V electricity potential (IEA/ PELLAND Y POISSANTE } & $12 \%$ & 2308,3 & 1948,5 & 2005,9 & 1570,7 & 1048,8 & 900,4 & 947,7 & 1292,9 & 1596,5 & 1979,0 & 2035,6 & 2154,3 & 1776,8 & 19788,7 \\
\hline
\end{tabular}

